\title{
Peran Modal Sosial dalam Pendidikan Sekolah
}

\author{
Muhammad Rijal Fadli \\ Pascasarjana Universitas Negeri Yogyakarta \\ Email: rijalfadli.co@gmail.com
}

\begin{abstract}
The purpose of this article is to describe the role of social capital in school education. The role of social capital in contributions has not yet been approved as an important aspect in the process of improving school quality. There are thoughts about schools that have not been discussed and do not consider important social capital is very important to be developed in the patterns of social relations that occur in the learning process both within the family, community and at school. The method in this research uses the literature method. The results of research that explain about social capital are very effective that is able to develop and maintain social capital itself, increasing the role of social capital will appear to increase and continue to build and develop trust, values/norms and social networks, cooperation and involvement in relationships for improving school quality improvement.
\end{abstract}

Keywords : Social Capital, Education, Schools

Abstrak. Tujuan dalam artikel ini adalah mendeskripsikan peran modal sosial dalam pendidikan sekolah. Peran modal sosial pada dasarnya masih belum dinilai sebagai aspek penting dalam proses perbaikan kualitas sekolah. Ada kecenderungan bahwa sekolah masih belum menyadari dan belum menganggap penting bahwa modal sosial sangat strategis untuk dikembangkan dalam pola-pola hubungan sosial yang terjadi dalam proses belajar baik di dalam keluarga, masyarakat dan di sekolah. Metode dalam penelitian menggunakan metode kepustakaan. Hasil penelitian menjelaskan bahwa modal sosial sangat efektif apabila mampu mengembangkan dan mempertahankan dari unsur-unsur modal sosial itu sendiri, sehingga peran modal sosial itu akan nampak apabila terus membangun dan mengembangkan kepercayaan, nilai/norma dan jaringan sosial, kerjasama dan partisipasi dalam rangka untuk meningkatkan perbaikan kualitas sekolah.

Kata Kunci : Modal Sosial, Pendidikan, Sekolah

\section{PENDAHULUAN}

Konsep modal sosial menurut Putnam (1993: 11-18) merupakan gambaran kehidupan sosial yang memungkinkan partisipan bertindak bersama secara lebih efektif untuk mencapai tujuan bersama. Putnam (1993) telah mengidentifikasi komponen-komponen kunci dari modal sosial dan keberadaannya merupakan prakondisi untuk pembangunan wilayah dan sistem pemerinthan yang efektif. Dalam pengembangan konsep modal sosial sebagai suatu teori diperlukannya sebuah unsur seperti kepercayaan, norma-norma dan jaringan yang pada dasarnya dapat dipandang sebagai suatu modal (Hauberer, 2011: 42).

Pengembangan modal sosial (social capital) dalam sistem pendidikan yang sentralistik mematikan kemampuan berinovasi, tentunya tidak sesuai dengan pengembangan masyarakat demokrasi yang terbuka. Oleh karena itu, desentralisasi pendidikan berarti lebih mendekatkan proses pendidikan kepada rakyat sebagai empunya pendidikan itu sendiri. Rakyat harus berpartisipasi di dalam pembentukan modal sosial tersebut. Keikut sertaan masyarakat di dalam penyelengggaraan pendidikan dalam suatu masyarakat demokratis berarti pula rakyat ikut membina lahirnya modal sosial (social capital) dari suatu bangsa (Fathurrohman, 2019). 
Konsep modal sosial merupakan unsur terpenting yang diharapkan mampu membentuk untuk meningkatkan kualitas sekolah. Modal sosial adalah hal penting untuk meningkatkan kualitas sekolah karena memuat, nilai-nilai, norma-norma, kepercayaan, kerjasama, jaringan sosial dan partisipasi. Modal sosial sendiri dapat dikatakan penting apabila unsur-unsur yang terdapat di dalam modal sosial mampu membantu meningkatkan kualitas sekolah. Dalam hal ini, kualitas sekolah dipengaruhi oleh bagaimana sekolah dapat memanfaatkan peran modal sosial yang telah dimiliki oleh sekolah. Kunci keberhasilan suatu negara ditentukan oleh sejauh mana masyarakat dengan sekolah bekerjasama dalam meningkatkan kualitas sekolah.

Peran modal sosial pada dasarnya masih belum dinilai sebagai aspek penting dalam proses perbaikan kualitas sekolah. Ada kecenderungan bahwa sekolah masih belum menyadari dan belum menganggap penting bahwa modal sosial sangat strategis untuk dikembangkan dalam pola-pola hubungan sosial yang terjadi dalam proses belajar di dalam keluarga atau di sekolah. Bahkan masyarakat cenderung belum menyadari apa dan bagaimana peran modal sosial itu sendiri yang dikembangkan dalam perbaikan kualitas peserta didik dan sekolah. Fenomena ini sangat menarik untuk dikritisi bahwa adanya kecenderungan modal sosial justru malah melemah, bahkan mulai tidak dianggap penting oleh orang tua dan para pengelola pendidikan. Realitas ini membuktikan bahwa adanya paradoks yang terus berkembang dalam kehidupan masyarakat akan ada peran modal sosial, sebagai modal penting bagi perbaikan kualitas pendidikan dan pihak hubungan lembaga dan non lembaga adalah sama (Dwiningrum, 2014: 164).

Dengan demikian modal sosial pada intinya berbicara mengenai persoalan hubungan. Dengan membangun hubungan dengan sesama dan menjaganya agar terus berkembang dan berlangsung sepanjang zaman, orang akan mampu bekerjasama untuk mencapai berbagai hal yang tidak dapat mereka lakukan sendiri, atau yang dapat mereka capai tetapi dengan susah payah (Pelu, 2016). Orang berhubungan melalui serangkain jaringan dan mereka cenderung memiliki kesamaan nilai dengan anggota lain dalam jaringan tersebut. Jaringan tersebut akan menjadi sumber daya, dan nantinya dapat dipandang sebagai modal. Selain dapat memberi manfaat langsung, modal-modal ini seringkali bisa dimanfaatkan dalam latar yang lain. Jadi semakin banyak jaringan yang kita bangun (menganl satu sama lain) maka semakin banyak kita memiliki kesamaan cara pandang dengan mereka, sehingga semakin banyak modal sosial kita.

Dalam pendidikan sekolah modal sosial sangat dibutuhkan untuk membangun jejaring antar sesama komunitas atau kelompok (sekolah lain). Tujuannya agar apa yang telah dibangun dapat berkembang dan mendapat amanah dari kalangan serta dapat meningkat kualitas dari sekolah itu sendiri. Dalam hal ini akan menggali lebih dalam mengenai peran modal sosial di pendidikan sekolah.

\section{METODE}

Metode yang digunakan dalam penelitian ini adalah metode kepustakaan (library research), dimana metode ini merupakan metode pengumpulan data dengan cara memahami dan mempelajari teori-teori dari berbagai literatur yang berhubungan dengan penelitian. Menurut Zed (2004: 14) ada empat tahap metode kepustakaan yaitu menyiapkan perlengkapan alat yang diperlukan, menyiapkan bibliografi kerja, mengorganisasikan waktu dan membaca serta mencatat bahan penelitian.

Dengan demikian, peniliti melakukan pengumpulan data dengan cara mencari dan merkontruksi dari berbagai sumber seperti buku, arsip, majalah, dokumen-dokumen tua, jurnal, dokumentasi, surat-surat kabar dan lain-lain (Simanjutak dan Sosrodihardjo, 2014). Dalam penelitian

kepustakaan ini peniliti memperhatikan langkah-langkah dalam meneliti kepustakaan, memperhatikan metode penelitian dalam rangka mengumpulkan data, membaca dan mengolah bahan pustaka serta peralatan yang harus dipersiapkan dalam penelitian tersebut, kegunaannya mempermudah peneliti dalam mendapatkan data (Khatibah, 2011). 


\section{HASIL DAN PEMBAHASAN}

\section{Modal Sosial}

Konsep modal sosial menurut Pierre Bourdieu (Eropa) adalah suatu upaya untuk membentuk agen sosial dalam habitus (modal sosial yang terbentuk sejak manusia lahir) (Field, 2010: 21), sebagai individu-individu yang mengkontruksi dunia sekelilingnya. Konsep modal sosial yang dikembangkan oleh Bourdieu tidak sebagai sesuatu yang berdiri sendiri, namun terkait dengan berbagai modal lainnya. Dalam kehidupan masyarakat dikenal dengan tiga jenis modal sosial yakni modal ekonomi, modal budaya dan modal sosial (Dwiningrum, 2014: 5).

James Coleman (Amerika) banyak memberikan pengaruh modal sosial dalam pendidikan. Menurutnya modal sosial merupakan presentasi dari sumber daya manusia, sebab hal ini melibatkan harapan akan resiprositas, dan melampui individu manapun sehingga melibatkan jaringan yang lebih luas yang hubungannya diatur oleh tingginya tingkat kepercayaan dan nilai-nilai bersama (Field, 2010: 32). Coleman juga memberi batasan modal sosial sebagai seperangkat sumber daya yang menjadi siat dalam hubungan keluarga dan organiisasi sosial komunitas yang berguna bagi perkembangan kognitif atau jiwa sosial anak/remaja (Syahra, 2003). Coleman memberikan anggapan bahwa modal sosial harus diperlakukan sebagai barang umum daripada sebagai barang pribadi. Baginya modal sosial didefinisikan berdasarkan fungsinya.

Francis Fukuyama menjelaskan modal sosial dalam Hasbullah (2006) modal sosial berdasarkan karakter sosial budaya masyarakat terdiri dari dua jenis, yaitu modal sosial terikat dan modal sosial yang menjembatani. Perbedaan keduanya dapat ditemui melalui penggambaran karakter-karakter sosial budaya di masyarakat yang terkait dengan karakter setiap modal sosial. Modal sosial terikat dicirikan oleh (Soekanto, 2002; Hasbullah, 2006): (a) Kelompok, dalam konteks ide, relasi dan perhatian, lebih berorientasi ke dalam dibandingkan ke luar. Ragam masyarakat atau individu yang menjadi anggota kelompok ini umumnya homogen, misalnya seluruh anggota kelompok berasal dari suku atau pemeluk agama yang sama; (b) Perhatian terfokus pada upaya menjaga nilai-nilai yang turun-temurun telah diakui dan dijalankan sebagian dari tata perilaku dan perilaku moral dari suku atau entitas sosial tersebut. Mereka cenderung konservatif dan lebih mengutamakan solidarity making daripada hal-hal yang lebih nyata untuk membangun diri dan kelompok sesuai dengan tuntutan nilai-nilai dan norma masyarakat yang lebih terbuka (Pontoh, 2010: 131).

Menurut Putnam (2000) bahwa modal sosial bagian dari kehidupan sosial-jaringan, norma dan kepercayaan yang mendorong partisipan bertindak secara lebih efektif untuk mencapai tujuan bersama. Suharjo (2014: 73) menerangkan bahwa modal sosial didefinisikan sebagai keadaan seperangkat nilai-nilai/norma-norma informal bersama yang digunakan diantara anggota kelompok yang memungkinkan berkerjasama diantara mereka. Maksud dari penjelasan Putnam dalam Acar (2011: 458) menganai soal jaringan sosial, jaringan ini nantinya akan memberikan manfaat sosial kepada individu, seperti memberikan informasi, menambah rasa percaya diri dan hubungan timbal balik yang kesemua itu dapat membantu orang dalam menyelesaikan masalah baik individu maupun kolektif lebih dengan mudah.

Dengan demikian, berdasarkan uraian di atas, sudah banyak dijelaskan oleh para ahli menganai modal sosial, maka modal sosial bisa dikatakan sebagai sesuatu yang merujuk pada norma-norma yang membentuk kualitas hubungan-hubungan yang tercipta, dan merujuk pada norma-norma yang membentuk kualitas hubungan dalam masyarakat. Pada saat ini modal sosial terus berkembang seperti halnya Bank Dunia. Damsar (2011: 183) Modal sosial juga dapat merujuk pada kekuatan untuk meningkatkan perkembangan ekonomi dalam suatu masyarakat dengan menciptakan dan mempertahankan hubungan sosial dan pola organisasi sosial. Usman (2018: 4) modal sosial bisa dilazimkan apabila dikaitkan dengan upaya mengelola, meningkatkan dan mendayagunakan relasirelasi sosial sebagai sumber daya yang diinvestasikan untuk memperoleh keuntungan ekonomi atau manfaat sosial. Maka premis dari modal sosial itu terletak pada hubungan sosial, sebab dengan hubungan sosial dapat mendatangkan keuntungan-keuntungan melalui dari proses interaksi sosial 
seperti adanya rasa saling percaya, sama pandangan dan nilai-nilai yang dianut secara bersama akan membentuk ikatan sosial yang kuat antar sesama.

\section{Unsur dan Bentuk Modal Sosial}

Dalam hal ini unsur dan bentuk modal sosial melihat dari tiga konsep yang terakomodir yaitu melalui norma, jaringan, dan kepercayaan. Disatu sisi modal sosial dijadikan sebagai sumber daya yang saling berkaitan satu dengan lainnya agar terjadinya saling mendukung (perubahan sosial).

\section{a. Norma}

Dalam konsep norma yakni memberikan pedoman bagi seseorang untuk bertingkah laku dalam masayarakat. Kekuatan mengikat norma-norma tersebut sering dikenal dengan empat pengertian antara lain cara (usage), kebiasaan (folkways), tata kelakuan (mores), dan adat istiadat (custom) (Soekanto, 2010: 174). Secara umum norma merupakan nilai yang bersifat kongkret. Diciptakan untuk menjadi panduan bagi setiap individu untuk berperilaku sesuai dengan aturan yang berlaku di masyarakat. Terkait hal ini, Putnam (2000) menjelaskan bahwa nilai-nilai terkandung di dalam suatu jaringan sosial. Dengan demikian dapat dikatakan bahwa posisi nilai-nilai menjadi penting sebagai pengikat atau perekat-kohesivitas-mempersatukan dalam menjalin hubungan (Fathy, 2019: 6). Menurut Fukuyama (2005: 179) sebenarnya umumnya norma yang terbentuk dengan spontan cenderung bersifat informal, artinya tidak dituliskan dan diumumkan. Selain merentangkan normanorma sosial, mulai dari norma sosial hierarkis hingga norma spontan, kita juga dapat merentangkan norma lainnya hasil pilihan rasional, serta norma turun menurun dan arasional. Nirfadhilah (2016: 4) menjelaskan bahwa norma merupakan nilai bersama yang mengatur perilaku individu dalam suatu kelompok/masyarakat.

\section{b. Jaringan}

Jaringan ialah sekelompok orang yang memiliki norma-norma atau nilai-nilai informal di samping norma-norma atau nilai-nilai yang diperlukan untuk transaksi biasa di pasar Fukuyama, 2005: 245). Jaringan (net-work) sosial adalah ikatan antarsimpul (orang atau kelompok) yang dihubungkan antarmedia (hubungan sosial). Hubungan sosial ini diikat oleh kepercayaan, bentuk strategis, dan bentuk moralitas. Kepercayaan itu dipertahankan oleh norma yang mengikat pihak-pihak yang berinteraksi (Agus Salim. 2008: 73). Pada dasarnya jaringan dalam hal sosial merupakan salah satu dimensi sosial selain kepercayaan dan norma. Konsep ini dalam kapital sosial lebih memfokuskan pada aspek ikatan antar simpul yang bisa berupa orang atau kelompok. Dalam hal ini terdapat adanya sebuah hubungan sosial yang diikat oleh adanya kepercayaan dan nantinya akan dipertahankan dan dijaga oleh norma-norma yang ada, sehingga pada konsep jaringan ini terdapat unsur kerja yang melalui hubungan sosial. Jaringan sosial sendiri nantinya terbentuk karena adanya rasa saling tahu, saling menginformasikan, saling membantu dalam melaksanakan atau mengatasi masalah. Pada intinya konsep jaringan dalam capital social merujuk kepada hubungan sosial yang memungkinkan kegiatan dapat berjalan dengan efesien dan efektif (Nirfadhilah, 2016: 3).

\section{c. Kepercayaan}

Kepercayaan merupakan harapan yang muncul dalam sebuah kelompok yang berlaku normal, jujur dan kooperatifberdasarkan norma-norma yang dimiliki bersama demi kepentingan bersama. Melalui kepercayaan orang-orang dapat bekerjasama secara efektif, sebab ada kesediaan antara mereka untuk menempatkan kepentingan kelompok tersebut (Fukuyama, 2002: 25). Pada dasarnya Hasbullah (2006: 63) kepercayaan dalam modal sosial adalah proses untuk mengakui kapasitas seseorang dalam menjalanka sebuah visi dan misi. Kepercayaan yang didapatkan oleh sebuah kelompok karena hasil yang telah terlihat secara nyata. Sebuah kelompok yang memiliki modal sosial berupa kepercayaan karena adanya keterjalinan proses interaksi sosial yang lama serta kegiatan yang sering dilakukan secara bersama. Dalam konsep kepercayaan Lawang (2004: 36) menyimpulkan bahwa 1) Hubungan sosial antar dua orang atau lebih, 2) Harapan yang akan terkandung dalam hubungan, apabila direalisasikan tidak akan merugikan satu sama lain, 3) Interaksi yang 
memungkinkan hubungan dan harapan supaya terwujud. Maka hubungan saling percaya (trust) akan dapat membangun kerjasama yang nantinya dapat menekan biaya transaksi antara orang, yang berarti menghemat penggunaan sumber daya.

Coleman (2011) berpendapat bahwa terdapat 6 bentuk modal sosial: kewajiban dan ekspektasi, saluran informasi, norma dan sanksi efektif, relasi wewenang, organisasi sosial yang disesuaikan, organisasi yang disengaja. Terkait hal tersebut, Haridison (2013:35) menerangkan dalam enam aspek. Pertama, kewajiban dan ekspektasi. Jika A melakukan sesuatu untuk B dan percaya bahwa B akan membalasnya pada masa depan, hal ini menciptakan ekspektasi di pihak A dan kewajiban di pihak B untuk memelihara kewajiban tersebut. Kedua, saluran informasi. Potensi informasi yang melekat pada relasi-relasi sosial. Informasi penting untuk mendasari tindakan, tetapi akuisisi informasi merugikan. Informasi sekurang-kurangnya memerlukan perhatian, yang selalu cepat diberikan. Alat yang dapat digunakan untuk mendapatkan informasi adalah penggunaan relasi sosial yang dipertahankan untuk tujuan lain. Ketiga, norma dan sanksi efektif. Norma-norma preskriptif yang merupakan bentuk modal sosial sangat penting dalam kolektivitas adalah norma yang membuat seseorang melepaskan kepentingan diri sendiri untuk bertindak demi kepentingan kolektivitas. Keempat, relasi wewenang. Jika pelaku A mengalihkan hak kendali beberapa tindakan kepada pelaku lain, B, maka B menyediakan modal sosial dalam bentuk hak kendali tersebut. Kelima, organisasi sosial yang dapat disesuaikan. Organisasi yang didirikan untuk satu rangkaian tujuan juga dapat membantu tujuan lainnya. Keenam, organisasi yang disengaja. Penggunaan konsep modal sosial tergantung pada keberadaan hasil sampingan aktivitas yang diikutsertakan untuk tujuan lain.

Pantoja (2000) membedakan bentuk-bentuk modal sosial sebagai berikut : (1) hubunganhubungan keluarga dan kekerabatan, meliputi: rumah tangga, keluarga luas, atau klien berdasarkan pada kuatnya pertalian darah dan afinitas; (2) jejaring sosial atau kehidupan asosiasional, meliputi: jejaring yang dimiliki individu, kelompok dan organisasi-organisasi yang menghubungkan individu dari keluarga-keluarga yang berbeda, atau kelompok-kelompok yang memiliki kesamaan aktivitas untuk berbagai maksud; (3) keterkaitan lintas sektor, termasuk jejaring yang menghubungkan organisasiorganisasi dari berbagai sektor di dalam masyarakat (LSM, organisasi akar rumput, perwakilan pemerintah, perusahaan swasta) yang memungkinkan kombinasi sumberdaya dan tipe pengetahuan yang berbeda-beda guna menemukan pemecahan masalah dari masalah-masalah yang kompleks. Bentuk modal sosial ini menyediakan artikulasi antara asosiasi dan organisasi yang bersifat horisontal dan vertikal; (4) normanorma dan nilai-nilai sosial, mencakup kepercayaan budaya yang luas dan pengaruh kepercayaan yang dimaksud terhadap berfungsinya masyarakat secara umum. Normanorma dan nilai-nilai mendukung bentuk-bentuk modal sosial lainnya sekaligus merepresentasi bentuk paling umum dan paling sulit dari modal sosial.

\section{Peranan Modal Sosial}

Peran modal sosial bisa dapat memunculkan sebuah pertanyaan, apa sebenarnya peran modal sosil itu? Bagaimana orang mendayagunakan relasi-relasi sosial sehingga menjadi sumber daya (resources) yang dapat diinvestasikan untuk tujuan memperoleh keuntungan ekonomi atau manfaat sosial. Bagaimana orang dapat merealisasikan tujuan tersebut? Jawabannya dapat ditelusuri dari efek atau dampak dari relasi-relasi sosial itu sendiri (Usman, 2018: 5).

Pertama, relasi-relasi sosial telah memfasilitasi aliran informasi tentang berbagai macam kebutuhan lingkungan. Semakin luas jejaring relasi sosial yang dapat dikembangkan semakin banyak pula informasi yang diperoleh. Disatu sisi penguasaan memiliki peran penting dalam upaya mengindentifikasi dan memprediksi kebutuhan yang berkembang dalam masyarakat. Disisi lain, penguasaan informasi memiliki peran penting dalam upaya membuat perkiraan atau prediksi mengenai sumber daya yang layak diinvestasikan dengan sesuai kebutuhan. Kedua, relasi-relasi sosial berkorelasi positif dengan pengaruh yang mampu menjadi kekuatan mobilitas dukungan. Oleh karena itu, semakin kuat relasi yang dibangun maka semakin kuat pula terhadap pengaruh posisi tawar kekuasaan. Ketiga, relasi-relasi sosial merupakan media untuk menanamkan dan menebarkan trust 
(nilai-nilai kepercayaan terhadap perkembangan), sehingga orang dapat mengembangkan hubungan yang saling menguntungkan satu sama lain (reciprocal relationships). Keempat, relasi-relasi sosial adalah media untuk mempertegas identitas sehingga orang mudah mengembangkan hubungan yang saling menghargai (recognition). Hubungan saling menghargai itu dapat menciptakan kondisi yang kondusif untuk berbagai kepentingan dan sumber daya. Hubungan semacam ini bukan hanya memberi rasa aman melainkan memberi jaminan keberlangsungan kegiatan (Usman, 2018: 5-6).

Dalam relasi-relasi sosial melibatkan individual aktor (subjek yang menjalin hubungan sosial) sekaligus kelompok (group), komunitas (community), dan masyarakat luas (society) yang menjadi tempat tumbuh dan berkembangkan relasi-relasi sosial tersebut. Jadi dalam pembahasan modal sosial terletak pada level individual aktor sebenarnya lebih fokus pada mengidentiffikasi bagaimana aktor tersebut berinvestasi pada relasi-relasi sosial, dan bagaiman aktor dapat menciptakan peluang untuk memanfaatkan sumber daya yang ada dan untuk mendapatkan keuntungan.

Modal sosial memiliki peranan yang cukup signifikan dalam pembangunan sumber daya manusia di dalam berbagai bidang. Seperti halnya dalam skala kelompok, bahwa modal sosial telah memfasilitasi tindakan koordinasi yang didasarkan atas kepercayaan, yang terbangun diantara anggota. Dalam sebuah kelompok yang tingkat modal sosialnya tinggi perilaku kerjasama dapat difasilitasi dengan tingkat kepercayaan yang tinggim dan norma timbal balik atau perilaku yang kuat didasarkan atas alasan lain dari pada mementingkan diri sendiri (Svendsen, 2009: 77). Menurut Subekti (2011: 7-10) peranan modal sosial sangat penting apabila diterapkan dalam kehidupan yang didasarkan atas beberapa alasan diantaranya:

1. Modal sosial dapat membantu dalam mempersiapkan anak untuk suatu pekerjaan.

2. Modal sosial dapat membantu dalam memberikan keterampilan dasar.

3. Modal sosial dapat membantu dalam membuka kesempatan memperbaiki nasib.

4. Modal sosia dapat membantu dalam menyediakan tenaga pembangunan.

5. Modal sosial dapat membantu dalam memecahkan masalah-masalah sosial.

6. Modal sosial dapat membantu mentransmisi kebudayaan.

7. Modal sosial dapat membantu dalam membentuk manusia yang berjiwa sosial.

8. Modal sosial dapat membantu da;am mentransformasi kebudayaan.

Dengan demikian bahwa modal sosial sama sepertinya dengan modal fisik dan modal finansial serta modal manusia yang dapat digunakan sebagai pendukung dalam mencapai suatu tujuan yang diharapkan bersama.

Dalam dunia pendidikan, peran dari modal sosial belum bisa dinilai sebagai aspek terpenting dalam proses perbaikan kualitas pendidikan. Padahal modal sosial memiliki peran yang sangat strategis untuk dikembangkan dalam pola-pola hubungan sosial yang terjadi dalam proses pembelajaran, baik di dalam keluarga maupun sekolah. Seperti yang dinyatakan oleh Suyata (2010: 35) pemahaman dan pemanafatan modal sosial tepat digunakan dalam menghadpi perubahan cepat yang terjadi dalam dunia pendidikan dan konteksnya seperti dievolusi kewenangan ke tingkat yang lebih rendah, kebutuhan adanya keterkaitan lintas sektor, dan penyebaran pengambilan keputusan ke masyarakat lokal dan kelompok volunter.

Modal sosial tersebut dapat digunakan dalam sebuah organisasi atau komunitas apapun, termasuk dalam pendidikan. Modal sosisal dalam pendidikan muncul dengan adanya interaksi antara orang-orang dalam komunitas pendidikan. Modal sosial sendiri merupakan potensi yang dimiliki masyarakat yang belum banyak digali, dikembangkan dan dimanfaatkan oleh dunia pendidikan. Namun demikian, modal sosial sendiri masih kurang dimanfaatkan dalam dunia pendidikan.

\section{Optimalisasi Modal Sosial di Pendidikan Sekolah}

Pendidikan merupakan pilar utama dalam tegaknya bangsa. Melalui pendidikan akan tegak dan mampu menjaga martabat bangsa. Dalam UU No. 20 tahun 2003 pasal 3 sistem pendidikan nasional menyebutkan bahwa pendidikan berfungsi mengembangkan kemampuan dan membentuk watak 
serta peradaban bangsa yang bermartabat dalam rangka mencerdaskan kehidupan bangsa, bertujuan untuk mengembangkan potensi peserta didik agar menjadi manusia yang beriman dan bertaqwa pada tuhan Yang Maha Esa, berakhlak mulia, sehat, berilmu, cakap, kreatif, mandiri, dan menjadi warga negara yang demokratis seta bertanggung jawab. Tentu saja dalam pelaksanaannya penyelenggara pendidikan atau sekolah harus berupaya untuk merealisasikannya (El-Khuluqo, 2015: 3).

Sekolah merupakan media pengembangan kehidupan sosial yang baik bagi anak dan pemuda untuk memperoleh pendidikan dan belajar dalam rangka mewujudkan manusia yang baik dan cerdas. Sejatinya sekolah sudah memiliki modal sosial dan budaya untuk menjadi alat untuk meningkatkan kualitas pendidikan di sekolah. Namuan realitas sosialnya ada kecenderungan bahwa dalam dunia pendidikan peran modal sosial masih belum dinilai sebagai aspek terpenting dalam proses perbaikan kualitas pendidikan. Ada kecenderung bahwa sekolah belum menyadari dan menganggap penting bahwa modal sosial sangat strategis untuk dikembangkan dalam pola-pola hubungan sosial yang terjadi dalam proses pembelajaran di dalam keluarga dan sekolah (Dwiningrum, 2014: 178).

Upaya untuk mengatasi masalah substansial membutuhkan respon proaktif dari sekolah. Dalam konteks inilah sekolah tidak hanya dimaknai lembaga formal yang memiliki fungsi sosial, tetapi sekolah memiliki peran penting dalam merespon dinamika kehidupan masyarakat. Kajian tentang sekolah akan terus berkembang maka eksistensi sekoah harus memiliki peran penting dalam menjaga ketertiban sosial. Sekolah mempunyai peran penting dalam sosialisasi masyarakat, baik secara personal maupun sosial. Modal sosial sendiri merupakan sumber daya yang dapat dipandang sebagai investasi sumber daya yang baru, dimana sumber daya adalah sesuatu yang dapat digunakan untuk dikonsumsi, disimpan, dan diinvestasikan. Sumber daya disini yang digunakan untuk investasi disebut dengan modal. Dimensi modal sosial sendiri cukup luas dan kompleks, sehingga pada modal sosial lebih menekankan terhadap potensi kelompok daln pola-pola hubungan individu dalam suatu kelompok dan antar kelompok dengan ruang perhatian pada jaringan sosial, norma/nilai dan kepercayaan antarsesama yang lahir dari anggota kelompok dan menjadi norma kelompok.

Selain unsur pembentukan modal sosial tersebut terdapat pula unsur pebentuk lain dai modal sosial yang tidak kalah penting peranannya. Unsur-unsur ini dapat diartikan sebagai syarat kecukupan dari terbentuknya atau terbangunnya kekuatan modal sosial di dalam masyarakat. Adapun unsur yang dimaksud adalah partisipasi dalam jaringan sosial, saling tukar kebaikan, norma sosial, dan tindakan proaktif (Hasbullah, 2009: 9-16). Dengan adanya modal sosial, kebijakan pendidikan desentralistik lebih mudah diimplementasikan di sekolah. Hal ini dapat terjadi karena modal sosial dapat saling dipertukarkan dengan kegiatan tertentu. Sebagaimana yang dijelaskan oleh Coleman bahwa bentuk modal sosial tertentu adalah sangat berguna dalam memfasilitasi tindakan tertentu, kerja sekolah dalam melakukan kebijakan apapun akan lebih efektif jika ada modal sosial.

Hal ini diperkuat dalam Dwiningrum (2014) bahwa pendekatan modal sosial di sekolah memberikan nilai tambah dalam peningkatan kualitas berupa; input peserta didik, sikap dan stakeholder sekolah, kompetensi kepala sekolah dan guru, lingkungan fisik sekolah, budaya sekolah, proses pembelajaran, hasil belajar peserta didik, kelembagaan sekolah. Disamping itu, pendekatan modal sosial yang efektif digunakan untuk perbaikan kualitas sekolah melalui lima tahapan; perbaikan lingkungan fisik sekolah, perbaikan iklim kerja stakeholder sekolah, sharing visi dan misi sekolah, pengembangan jaringan/networks serta pengembangan norma-norma sosial.

Menurut Pelu (2015: 120) proses pendidikan secara umum lebih bersifat individual dan kurang menekankan pada belajar kelompok. Selain itu, pendidikan juga lebih menkankan pada pengembangan aspek kognitif, sedangkan modal sosial adalah bagian dari proses sosial yang tidak hanya bersifat kognitif saja, tetapi juga bersifat efektif, baginya modal sosual adalah sebagai hasil dari kerjasama antar individu. Maka dari itu, pembentukan dan pemanfaatan modal sosial hanya bisa dilakukan dengan efektif apabila melibatkan jumlah orang yang bekerjasama dalam sebuah kelompok, kerjasama yang didasari rasa saling percaya dan komitmen pada aturan dan norma yang telah disepakati merupakan modal yang besar dalam mencapai perbaikan pendidikan di Indonesia (Pelu, 2016). 
Bagi sekolah optimalisasi modal sosial dimulai dari penguatan unsur-unsur modal sosial itu sendiri yang telah dimiliki oleh sekolah. Pertama, lebih berpartisipasi dalam berbagai jaringan sosial (participation and social network) yang menguatkan eksistensinya sebagai lembaga pendidikan yang dapat dipercayai oleh masyarakat untuk mengembangkan potensi peserta didik sebagai sumber daya pribadi yang mampu untuk berbagai dalam komunitas sekolah maupun sekolah. Kedua, mengkondisikan interaksi yang heterophilious untuk saling tukar menukar kebaikan agar peserta didik dapat mengembangkan potensi sumber daya sosialnya (reciprocity). Ketiga, membangun budaya sekolah untuk mempertahankan ketertiban dan disiplin sosial (social norm). Keempat, menanamkan kepercayaan dan rasa percaya diri dan tanggung jawab serta kerjasama sebagai modal penting untuk memperkuat modal sosial. Kelima, mengembangkan kemampuan pada semua stakeholder sekolah untuk melakukan tindakan yang proaktif dalam merespon perubahan yang terus terjadi (Huwaida, 2019).

Pengoptimalisasian modal sosial dalam sekolah sejatinya di setiap sekolah sudah mempunyai modal sosial masing-masing, tinggal seberapa gereget pihak sekolah untuk mengembangkan dan mengutkan semua modal sosial tersebut. Maka, dalam mengoptimalisasikan modal sosial di sekolah diperlukannya penguatan semua unsur-unsur dari modal sosial itu sendiri, yang dianggap sebagai energi sosial bagi upaya upaya perbaikan kualitas sekolah. Dalam kajian ini memberikan landasan kuat bagi sekolah-sekolah untuk mengembangkan kebijakan sekolah yang berbasis modal sosial, sehingga dapat mampu mengatasi kegagalan-kegagalan dan masalah dalam persoalan pengelolahan dan penyelenggaraan pendidikan yang dapat diatasi secara konseptual sesuai dengan kekuatan modal sosial yang telah dimiliki oleh sekolah.

Dengan demikian kajian ini memberikan beberapa solusi bagi sekolah-sekolah yang dirasa masih rendah tingkat modal sosialnya, solusinya adalah menguatkan dan terus mengembangkan unsur-unsur dari modal sosial itu sendiri diantaranya sebagai berikut.

Tabel 1. Peran Modal Sosial di Sekolah

\begin{tabular}{|l|l|l|}
\hline No. & \multicolumn{1}{|c|}{ Unsur } & \multicolumn{1}{c|}{ Deskripsi } \\
\hline 1. & Kepercayaan & $\begin{array}{l}\text { Kepercayaan masyarakat terbangun dengan seiring banyaknya } \\
\text { prestasi sekolah yang telah diraih dan kualitas sumber daya } \\
\text { sekolah yang ada. Hal inilah yang akan menjadikan bahan } \\
\text { pertimbangan-pertimbangan masyarakat untuk menyekolahkan } \\
\text { anak-anaknya mereka ke sekolah tersebut. Kepercayaan ini juga } \\
\text { menjadi landasan bagi hubungan antara sekolah dengan } \\
\text { berbagai pihak yang terlibat dalam program-program sekolah. }\end{array}$ \\
\hline 2. & Nilai/Norma & $\begin{array}{l}\text { Nilai dan norma yang ada di sekolah sangatlah penting yang } \\
\text { berupa tata tertib berisi aturan-aturan dan sanksi bagi yang } \\
\text { melakukan pelanggaran. Membuat nilai dan norma unggulan } \\
\text { yang dapat dijadikan pembeda dengan sekolah lain adalah nilai } \\
\text { dan norma itu digunakan untuk membangun sumber daya } \\
\text { peserta didik dalam membentuk watak peserta didik. }\end{array}$ \\
\hline 3. & Jaringan Sosial & $\begin{array}{l}\text { Jaringan sosial diperoleh dengan cara menjalin relasi-relasi sosial } \\
\text { dengan berbagai pihak yang berasal dari berbagai sumber daya } \\
\text { dalam meningkatkan hubungan sosial. }\end{array}$ \\
\hline 4. & Kerja Sama & $\begin{array}{l}\text { Kerjasama merupakan relasi yang terjalin antara kepala sekolah } \\
\text { dengan guru, guru dengan guru, guru dengan peserta didik } \\
\text { sekolah dengan wali murid dan sekolah dengan masyarakat. Jadi } \\
\text { sekolah harus bisa terus berkembang dalam mengoptimalkan } \\
\text { kerjasama antar sesama. }\end{array}$ \\
\hline 5. & Partisipasi & $\begin{array}{l}\text { Partisipasi adalah pelibatan warga sekolah baik kepala sekolah, } \\
\text { guru, karyawan, peserta didik, orang tua untuk membuat sebuah }\end{array}$ \\
\hline
\end{tabular}




\begin{tabular}{|l|l|l|}
\hline & $\begin{array}{l}\text { keputusan penting dan menumbuhkan rasa memiliki sekolah. } \\
\text { Dalam partisipasi semua elemen sekolah harus } \\
\text { mempertahankan dan mengembangkan apa yang sudah dimiliki } \\
\text { supaya satu dengan yang lainnya tidak miskomunikasi. }\end{array}$ \\
\hline
\end{tabular}

(Sumber: Adaptasi dari Huwaida, 2019)

\section{KESIMPULAN}

Modal sosial bisa dikatakan sebagai sesuatu yang merujuk pada norma-norma yang membentuk kualitas hubungan-hubungan yang tercipta, dan merujuk pada norma-norma yang membentuk kualitas hubungan dalam masyarakat. Modal sosial bisa dilazimkan apabila dikaitkan dengan upaya mengelola, meningkatkan dan mendayagunakan relasi-relasi sosial sebagai sumber daya yang diinvestasikan untuk memperoleh keuntungan ekonomi atau manfaat sosial. Maka premis dari modal sosial itu terletak pada hubungan sosial, sebab dengan hubungan sosial dapat mendatangkan keuntungan-keuntungan melalui dari proses interaksi sosial seperti adanya rasa saling percaya, sama pandangan dan nilai-nilai yang dianut secara bersama akan membentuk ikatan sosial yang kuat antar sesama, sehingga dalam pendidikan sekolah modal sosial dapat dijadikan sebuah jaringan untuk meningkatkan kualitas sekolah.

Pengoptimalisasian modal sosial dalam sekolah sejatinya di setiap sekolah sudah mempunyai modal sosial masing-masing, tinggal seberapa gereget pihak sekolah untuk mengembangkan dan mengutkan semua modal sosial tersebut. Maka, dalam mengoptimalisasikan modal sosial di sekolah diperlukannya penguatan semua unsur-unsur dari modal sosial itu sendiri, yang dianggap sebagai energi sosial sebagai upaya perbaikan kualitas sekolah. Landasan kuat bagi sekolah-sekolah untuk mengembangkan kebijakan sekolah yang berbasis modal sosial, sehingga dapat mampu mengatasi kegagalan-kegagalan dan masalah dalam persoalan pengelolahan dan penyelenggaraan pendidikan yang dapat diatasi secara konseptual sesuai dengan kekuatan modal sosial yang telah dimiliki oleh sekolah. Untuk mengoptimalkan modal sosial itu sendiri dengan cara meningkatkan dan

\section{DAFTAR PUSTAKA}

Acar, E. (2011). Effect of Social Capital on Academic Success: A Narrative Synthesis. Journal Educational Research \& Riviews, 6, 456-461.

Agus Salim. (2008). Pengantar Sosiologi Mikro. Yogyakarta: Pustaka Pelajar.

Agusyanto, R. (2010). Fenomena Dunia Mengecil: Rahasia Jaringan Sosial. Jakarta: Institut Antropologi Indonesia.

Damsar. (2011). Pengantar Sosiologi Pendidikan. Jakarta: Pranada Media.

Dwiningrum, S. I., A. (2014). Modal Sosial Dalam Pengembangan Pendidikan (Perspektif Teori dan Praktik). Yogyakarta: UNY Press.

Fathy, Rusydan. (2019). Modal Sosial: Konsep, Inklusivitas dan Pemberdayaan Masyarakat. Jurnal Pemikiran Sosiologi, 6 (1), 1-17.

Field, J. (2010). Social Capital. London: Routledge. Dalam Nurhadi (et.al). Modal Sosial. Yogyakarta: Kreasi Wacana.

Fukuyama, F. (2002). Trust: Kebijakan Sosial dan Penciptaan Kemakmuran. Yogyakarta: Qalam.

Fukuyama, F. (2005). Guncangan Besar: Kodrat Manusia dan Tata Sosial Baru. Penerjemah: Masri Maris. Jakarta: Gramedia Pustaka Utama.

Haridison, Anyualatha. (2013). "Modal Sosial dalam Pembangunan". JISPAR: Jurnal IImu Politik, Sosial dan Pemerintahan, 2 (2), 31-40.

Hasbullah, J. (2006). Social Capital (Menuju Keunggulan Budaya Manusia Indonesia). Jakarta: MRUnited Press.

Huwaida, Deskha Irbakh. (2019). Peran Modal Sosial dalam Perbaikan Kualitas Sekolah di SMP Muhammadiyah Plus Gunungpring. Skripsi. Tidak Diterbitkan. Yogyakarta: UNY.

Khatibah. (2011). Penelitian Kepustakaan. Jurnal Iqra', 5(1). 
Lawang, R.M.Z. (2004). Buku Materi Pokok Pengantar Sosiologi (modul 1-5). Jakarta: Universitas Terbuka.

Nirfadhilah. (2016). Jaringan Sosial dalam Penjualan Pedagang Makanan di Pasar Inpres Kelurahan Baqa Kecamatan Samarinda Seberang. Ejournal Sosiatri-sosiologi, 4 (1).

Pantoja, Enrique. (2000). Exploring the Concept of Social Capital and Its Relevance for CommunityBased Development: The Case of Coal Mining Areas in Orissa, India, The World Bank Social Development Family and Socially Sustainable Development Network, Social Capital Initiative, Working Paper No. 18. USA: Washington.

Pelu, Musa. (2016). Pendidikan Budi Pekerti di Sekolah: Refleksi Modal Sosial dan Modal Budaya (Studi Kasus di SMP Muhammadiyah 5 Surakarta dan SMP Kasatriyan 11 Surakarta). Disertasi. Tidak Diterbitkan. Yogyakarta: Universitas Negeri Yogyakarta.

Pelu, Musa. (2015). Pendidikan Budi Pekerti Di Sekolah. Jurnal Pembangunan Pendidikan: Fondasi dan Aplikasi, 3 (2), 198-213.

Pontoh, Otniel. (2010). Identifikasi Dan Analisis Modal Sosial Dalam Rangka Pemberdayaan Masyarakat Nelayan Desa Gangga Dua Kabupaten Minahasa Utara. Jurnal Perikanan dan Kelautan Tropis, 6 (3), 125-134.

Putnam, R. (2000). Bowling Alone: The Collapse and Revival of American Community. New York: Simon \& Shuster Paperbacks.

Soekanto, S. (2003). Sosiologi: Suatu Pengantar. Jakarta: PT. Raja Grafindo Persada.

Subekti. T. (2011). Social Capital sebagai Strategi Pengmebangan Madrasah. Makalah disampaikan dalam Seminar Nasional Prodi Ilmu Pendidikan Program Doktor Pascasarjana Universitas Negeri Yogyakarta.

Suharjo. (2014). Peran Modal Sosial dalam Perbaikan Kualitas Sekolah Dasar di Kota Malang. Disertasi. Tidak diterbitkan. Yogyakarta: Universitas Negeri Yogyakarta.

Svendsen, T.G. (2009). Handbook o Social Capital: The Troika of Sociology, Political Science and Economics. Massachusetts: Edward Elgar Publishing.

Syahra, R. (2003). Modal Sosial: Konsep dan Aplikasi. Jurnal Masyarakat dan Budaya, 5 (1).

Usman, Sunyoto. (2018). Modal Sosial. Yogyakarta: Pustaka Pelajar.

Fathurrohman, F. (2019). Pemanfaatan Modal Sosial dalam Peningkatan Kualitas Sekolah di SDIT

Bina Insan Kamil Turi. Skripsi. Tidak Diterbitkan. Yogyakarta: Universitas Negeri Yogyakarta.

El-Khuluqo, Ihsana. (2015). Manajemen PAUD Pendidikan Taman Kehiduapan Anak. Yogyakarta: Pustaka Pelajar.

Putnam, R.D. (1993). The Prosperous Community: Social Capital and Publicc Life. The American Prospect, 4 (13).

Simanjutak, Bungaran Antonius dan Sosrodihardjo, S. (2014). Metode Penelitian Sosial. Jakarta: Yayasan Obor.

Suyata. (2010). Pemberdayaan Pendidikan: Kepala Sekolah Logo Sekolah. Paper disampaikan dalam Workshop Strategi Pengembangan Kualitas Sekolah bagi Kepala Sekolah dan Pengawas Sekolah. Tanggal 7 Agustus 2010 di PPS UNY.

Zed, M. (2004). Metode Penelitian Kepustakaan. Yogyakarta: Yayasan Obor. 